Diabetologia 10, $211-214$ (1974)

(C) by Springer-Verlag 1974

\title{
Treatment of Insulin Lipoatrophy with Monocomponent Insulin
}

\author{
A. Teuscher \\ Medizinische Universitätsklinik, Inselspital, Bern, Switzerland \\ Received: September 10, 1973, and in revised form: February 5, 1974
}

Summary. A female diabetic with severe insulininduced lipoatrophy was successfully treated with a monocomponent (MC) Lente preparation. This patient was studied for over 6 years and, during periods of treatment with various insulins of different purity, a variety of reactions was observed in the adipose tissue. Evidence is presented that lipoatrophy may be caused by insulin impurities. Lipoatrophy occurring after treatment with recrystallized, mixed species Lente insulin was substantially reduced after treatment with 10 times recrystallized porcine Lente, but recurred on 4 times recrystallized beef Lente, also in areas where beef Lente was not injected. Beef insulin impurities seem more prone to produce lipoatrophy than pork insulin impurities. It is suggested that MC-insulin is the treatment of choice for this condition.

Key words: Lipoatrophy, lipodystrophy, insulin species, proinsulin, insulin impurities, monocomponent insulin, insulin antibodies.
A variety of factors have been investigated as possible causes of insulin-induced lipoatrophy, but the exact cause is still obscure. In a survey of 1096 consecutive diabetic patients of all ages, who had taken insulin for one year or longer, $24 \%$ had atrophy in some degree [1]. Such atrophy gives the appearance of subcutaneous fat having actually melted away and has been described as , a sharply defined disappearance of the subcutaneous fat without exudative reaction and appreciable fibrosis" $[2,3]$.

One of our patients was a female diabetic with grossly disfiguring insulin atrophy and, during a period of treatment of $6^{1} / 4$ years, we attempted not only to reduce the atrophy, but also, by using a series of purified insulins with different characteristics, to elucidate the mechanism of atrophy induction and reduction.

\section{Case Report}

The patient (M.S.), a married French woman, 50 years of age, was first seen in 1967 , at the age of 45 , complaining of severe atrophy at the sites of insulin injections in the lateral upper aspects of her thighs. Three months prior to the occurrence of the lesions she had been placed on Semilente (Novo) and later on a combination of Semilente and Lente insulin (Novo). This was the first time that this patient had received insulin.

Physical examination revealed localized areas of lipoatrophy in the lateral and upper aspects of both thighs, measuring $5 \mathrm{~cm}$ in depth and covering an area of $6 \times 10 \mathrm{~cm}$. At the base of the atrophied areas muscle fascia could be palpated and no subcutaneous adipose tissue could be felt. The borders of the regions were sharply delineated and showed no inflammatory reaction (Fig. 1.). The patient was put on a 1800 calorie diet (carbohydrate: $210 \mathrm{~g}$, protein: $80 \mathrm{~g}$, and fat: $65 \mathrm{~g}$ ). with 10 units of Semilente (Novo) and 18 units of Lente (Novo). The blood glucose values varied between 67 and $252 \mathrm{mg} / 100 \mathrm{ml}$. Her diabetes was of the stable type, but there was tendency for hypoglycaemia to develop in the forenoon.

During the $6^{\mathbf{1}} / 4$ year's observation period, 9 series of regimes were followed (Fig. 2).

\section{Special Investigations}

Biopsies of Adipose Tissue

During treatment period 6 and 7, biopsies of the adipose tissue were performed. Histology from the borders of the atrophy showed normal adipose tissue with normal capillaries and no cellular infiltration. There was no evidence of insulin antibodies when using an immunofluorescent technique. Adipose tissue was incubated with the monospecies beef insulin used at that time and, after washing, was treated with fluorescent insulin antibodies [4]. No immunochemical reaction was observed in the adipose tissue, including capillaries and arterioles (Prof. Hess, Depart. for Immunopathology, Path. Institute, University of Bern).

\section{Insulin Antibodies}

Insulin antibodies were determined frequently from the beginning of MC-insulin treatment [5]. The range with the various insulins is shown in Fig. 2. There seems to be no relation between the stage of lipoatrophy and the level of insulin antibodies. The highest values were measured during the last reparatory phase on Monotard. 


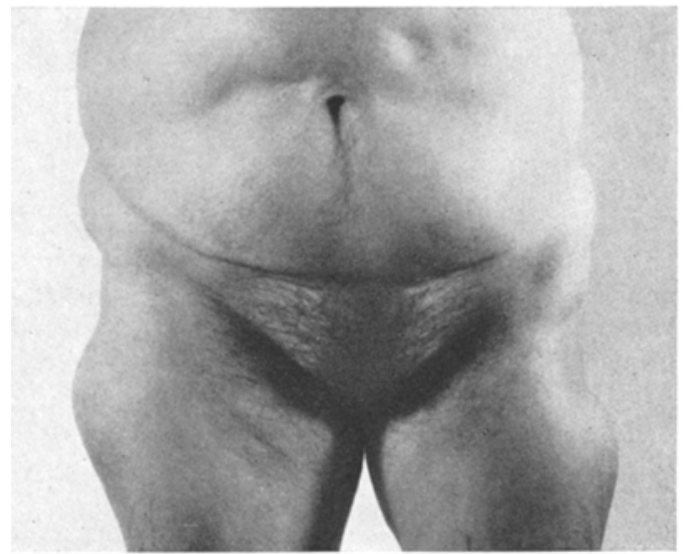

a)

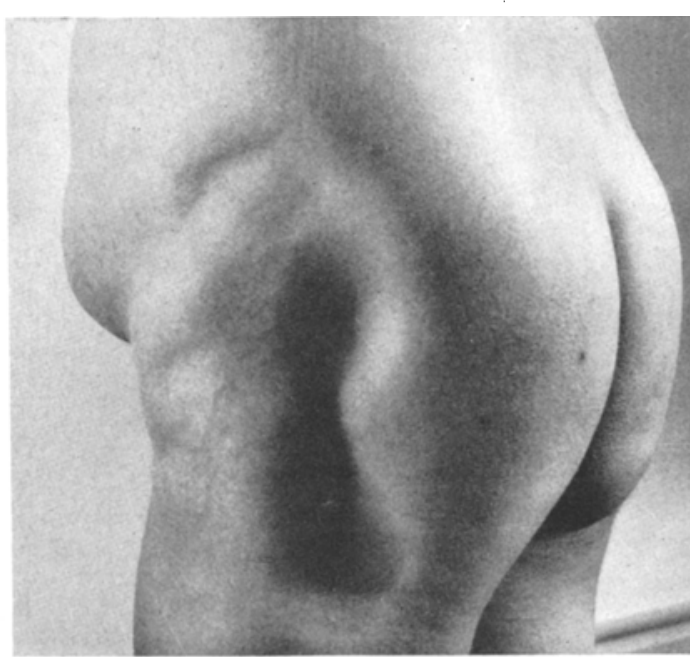

b)

Fig. 1a) b). Atrophy of subcutaneous fat tissue at the site of insulin injections in the upper part of the thighs and the abdomen. The muscles can be seen beneath the skin

\begin{tabular}{|c|c|c|c|c|c|c|c|c|c|c|}
\hline Period & Sept 67-Sept 68 & Oct 68 - Oct 69 & Nov $69-$ Sept 70 & Oct $70-$ May 71 & June 71 & July 71 -Dec 71 & $\operatorname{Jan} 72-J u n 72$ & July $72^{\prime}$ & Aug $72-$ Sept 72 & Oct $72-\operatorname{Jan} 74$ \\
\hline Lipoatrophy & & & & & & & & & & \\
\hline $\begin{array}{l}\text { Insulin: } \\
\text { species } \\
\text { purity } \\
\text { proinsulin } \\
\text { pH }\end{array}$ & $\begin{array}{c}\text { beef }+ \text { pork } \\
\text { 4x recryst. } \\
+ \\
7\end{array}$ & no insulin & $\begin{array}{c}\text { pork } \\
\text { MC } \\
0 \\
7\end{array}$ & $\begin{array}{c}\text { pork } \\
\text { 10xrecryst. } \\
+ \\
7\end{array}$ & $\begin{array}{c}\text { pork } \\
4 \text { x recryst. } \\
+ \\
7\end{array}$ & $\begin{array}{c}\text { pork } \\
\text { 10xrecryst. } \\
+ \\
7\end{array}$ & $\begin{array}{c}\text { beef } \\
\begin{array}{c}\text { xxrecryst. } \\
+ \\
7\end{array}\end{array}$ & $\begin{array}{c}\text { beef } \\
\begin{array}{c}4 \times \text { recryst } \\
+ \\
7\end{array}\end{array}$ & $\begin{array}{c}\text { beef } \\
\text { 10xrecryst. } \\
+ \\
7\end{array}$ & $\begin{array}{c}\text { pork } \\
\text { MC } \\
0 \\
7\end{array}$ \\
\hline $\begin{array}{l}\text { Treatment: } \\
\text { Insulin (u) } \\
\text { antidiabetics } \\
\text { oral }\end{array}$ & $\begin{array}{l}\text { Semilente } 10 \\
\text { Lente } 18\end{array}$ & $\begin{array}{l}\text { Tolbutamide } \\
\text { Tolazamide } \\
\text { Phenformin } \\
\text { Acetohexamid }\end{array}$ & Lente 16 & $\begin{array}{l}\text { Sermilente } 16 \\
\text { Lente } 16\end{array}$ & Semilente 16 & $\begin{array}{l}\text { Sernilente } 24 \\
\text { Lente } 24\end{array}$ & Lente 28 & Lente 28 & Lente 28 & Lente 22 \\
\hline $\begin{array}{l}\text { Insulin antibody }(\%) \\
\text { titer (n) }\end{array}$ & & $\begin{array}{c}2 \\
(1)\end{array}$ & $\begin{array}{c}2.5-17.5 \\
(8)\end{array}$ & $\begin{array}{c}6.9-25.7 \\
(7)\end{array}$ & $\begin{array}{c}14.9-15.8 \\
(2)\end{array}$ & $\begin{array}{c}4.3-17.1 \\
(5)\end{array}$ & $\begin{array}{c}19.8-21.1 \\
\text { (2) }\end{array}$ & $\begin{array}{c}31.3-33.7 \\
(2)\end{array}$ & $\begin{array}{c}29.6-30.4 \\
(2)\end{array}$ & $\begin{array}{c}22,2-36,5 \\
\text { (6) }\end{array}$ \\
\hline $\begin{array}{l}\text { Mean } \\
\text { blood-glucose } \\
\text { mg/tooml } \\
\text { (n) }\end{array}$ & $\begin{array}{ccc}227 & -94 & -99 \\
6 & 6 & 3\end{array}$ & $\begin{array}{ccc}193 & -190 & -185 \\
3 & 14 & 10\end{array}$ & $\begin{array}{ccc}117 & -153 & - \\
2 & 6 & 0\end{array}$ & $\begin{array}{ccc}- & 193 & - \\
0 & 9 & 0\end{array}$ & $\begin{array}{lcc}- & 212 & - \\
0 & 1 & 0\end{array}$ & $\begin{array}{cc}194-209 & - \\
45 & 0\end{array}$ & $\begin{array}{ccc}122 & -206 & -147 \\
1 & 6 & 1\end{array}$ & $\begin{array}{lc}- & 130 \\
0 & 1\end{array}$ & $\begin{array}{ccc}111 & 203 & - \\
1 & 2 & 0\end{array}$ & $\begin{array}{ccc}230 & 122 & 121 \\
6 & 12 & 3\end{array}$ \\
\hline
\end{tabular}

Fig. 2. Nine different treatment regimes in a case of insulin lipoatrophy. Period 1 (September 1967 - September 1968): treatment with (commercial) Semilente and Lente: progression of atrophy; during this period various technical alterations of insulin injections were evaluated. Period 2 (October 1968 - October 1969): treatment with oral antidiabetics: slow decrease of atrophy. Period 3 (November 1969 - September 1970): treatment of decompensated diabetes with Lente made from pork MC-insulin (Monotard): rapid improvement; combination with oral antidiabetics because of limited insulin supply. During this ten-month period the insulin-induced atrophy almost completely disappeared (Fig. 3). Period 4 (October 1970-May 1971): treatment with 10 times recrystallized pork insulin Semilente and Lente: continued improvement. Period 5 (June 1971): treatment with commercial Semilente: rapid exacerbation of lipoatrophy within 3 weeks, not only at the new site of injections in the abdomen, but also at all the sites where insulin had previously been given as far back as 1967. Period 6 (July - December 1971): treatment with 10 times recrystallized pork insulin Semilente and Lente pork insulin: slow improvement. Period 7 (January - July 1972): treatment with 4 times recrystallized beef insulin Lente for evaluation of species difference: some improvement and then recurrence within 2 weeks in all areas where beef insulin had been injected previously without reaction (Fig. 4). Period 8 (August - September 1972): treatment with 10 times recrystallized beef insulin Lente: slow progression. Period 9 (October 1972 - January 1974): treatment with Monotard: almost complete disappearance after 6 months and continued improvement for a total of 16 months 


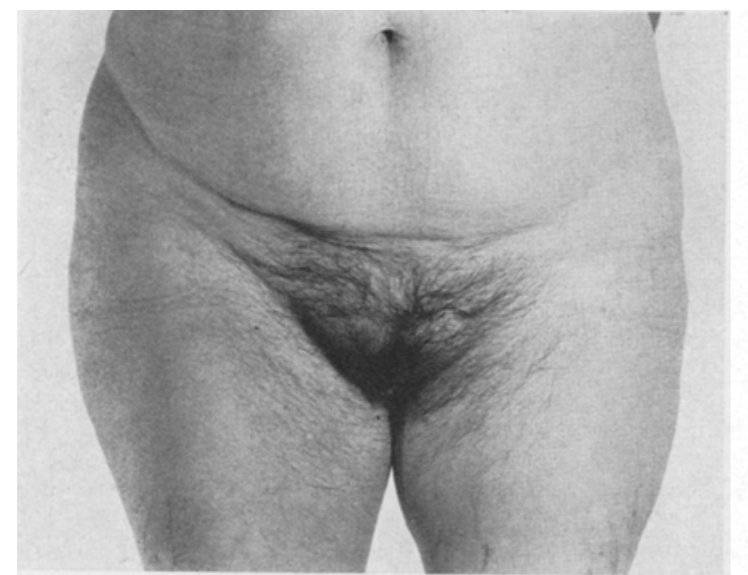

Fig. 3. Almost complete recovery after treatment with pork MC-insulin Lente (Monotard) for 11 months and 10 times recrystallized pork insulin Lente and Semilente for 8 months

\section{Skin Test}

Skin tests were performed with all relevant insulins, insulin components, and solvents, and no significant allergies were noted in comparison to histamine (1: 10000).

\section{Insulin Preparations and Methods}

The following insulins were kindly supplied by Novo Industri A/S, Copenhagen: Monotard; 10 times recrystallized pork insulin Semilente and Lente; 4 times recrystallized pork insulin Lente; 4 times reerystallized beef insulin Lente; 10 times recrystallized beef insulin Lente. Insulin antibodies were measured according to the method of Skom and Talmage [5].1 The immunofluorescent examination of adipose tissue was carried out by the method of Coons [4]; bloodglucose determinations were performed with glucose oxidase. Skin tests with Novo preparations were made at the Institute for Allergy and Clinical Immunology (Prof. A. de Weck) of the University of Bern.

\section{Discussion}

Lipoatrophy occurs in about one third of all insulin treated diabetios, mostly females. In most cases its development follows a common pattern, in that it appears after three to six months of treatment and subsides after $2-3$ years, thus suggesting a spontaneous desensitization, as seen in cases of skin allergy to insulin. Only a few cases of marked atrophy are seen after the age of twenty. Such resistant and severe forms of insulin atrophy are rare and suggest the presence of overriding idiosyncratic factors.

1 We are indebted to Prof. S. Fankhauser, Kantonsspital, Olten, for the determinations of insulin antibodies.

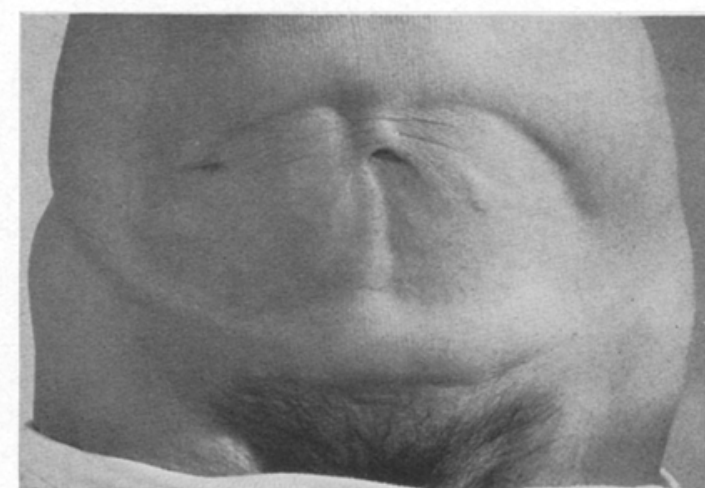

Fig. 4. Reappearance of insulin induced atrophy in the abdomen after 6 months of treatment with 4 times recrystallized beef insulin Lente. The atrophy progressed in a three week period, even after changing the site of injection to the hip

Knowles stated in a recent review [6] that the occurrence of lipoatrophy is decreasing. This may be due to use of more purified insulins. Nevertheless, there has been no satisfactory method of treating resistant forms.

Many factors which might be related to atrophy have been investigated in the course of many years. It has been noted that the condition is not related to insulin $\mathrm{pH}$, to the presence of preservatives such as tricresol in the insulin or to the presence of a lipase in exogenous insulin, to inflammatory processes, to the mechanical trauma of injections or to traces of alcohol, which might have been left in the syringe before the insulin was drawn $[2,3]$.

There is still no satisfactory explanation for its pathogenesis [7].

Insulin atrophy occurs in susceptible persons regardless of the variety of insulins used at present, with the exception of MC-insulin, with which we have not seen any atrophy. No cases have been reported in the literature to our knowledge. Our case report seems to indicate that the so-called "impurities" of insulin, including proinsulin, may be the causative factor in susceptible individuals.

Even with commercial, recrystallized insulins (Novo), such as Semilente (pork) and Lente (beef/ pork), atrophy may occur, as in our case. We found marked improvement of atrophy with MC-insulin, which is the purest insulin, free of all non-insulin components, including proinsulin, arginyl insulin, etc. and is virtually non-immunogenic [10]. As there was also no recurrence of atrophy with 10 times recrystallized pork insulin during an eight month period, we feel that pork proinsulin is probably not the factor responsible for the atrophy. But there are other insulin fractions in commercial pork insulins (Actrapid, Semilente) which may be the cause. In our patient 
beef insulin ( 4 times recrystallized MS beef Lente) seemed to show no adverse effects during the first 6 months of treatment, but then marked atrophy occurred while the patient was still on the same batch. It seems likely that beef insulin impurities, more immunogenic than pork insulin impurities, are also more harmful with regard to the development of lipoatrophy and, furthermore, that the amount and nature of impurities may vary in conventional insulins.

In five other female diabetics with insulin induced lipoatrophy of long duration ( 2 to 8 years), the lesions disappeared after 2 to 10 months' treatment with MC-insulin. In three patients, one of two symmetrical lesions was treated by injecting them from the periphery and within the atrophic areas and the beneficial effect occured only on the treated side.

\section{References}

1. Renold, A.E., Winegrad, A.I., Martin, D. B.: Diabète sucré et tissue adipeux. Helv. med. Acta 24, 322-327 (1957)

2. Marble, A., Smith, R.M.: Atrophy of subcutaneous fat following injections of insulin. Proc. Amer. Diab. Assoc. 2, (173) 1942
3. Marble, A., Renold, A.E.: Atrophy and hypertrophy of subcutaneous fat tissue to insulin. Trans. Ass. Amer. Phyens 62, 219 (1949)

4. Coons, A.H.: Fluorescent methods. In: General Cytochemical Methods, p. 400. (Ed. Danielli, J.F.) New York: Academic Press 1958

5. Skom, J.H., Talmage, D.W.: Nonprecipitating insulin antibodies. J. clin. Invest. 37, 783-786 (1958)

6. Knowles, H.C.: Diabetes mellitus in childhood and adolescence. Med. Clin. N. Amer. 55, 957-987 (1971)

7. Watson, B.M., Calder, J.S.: A treatment for insulininduced fat atrophy. Diabetes 20, 628-632 (1971)

8. Kljatschko, V., Tykina, T.N., Perelygina, A.A.: Schweineinsulin bei der Therapie der Zuckerkrankheit. Presented at the 2nd International Donausymposium on Diabetes Mellitus, p.p. 403-404. Budapest June 1971. (Ed. Magyar, I., Beringer, A. Wien: Verlag Wiener Med. Akademie

9. Schlichtkrull, J., Brange, J., Christiansen, H., Hallund, O., Heding, L. G., Jorgensen, K.H. : Clinical aspects of insulin antigenicity. Diabetes 21, Suppl. 2. $649-656(1972)$

10. Schlichtkrull, J.: Proinsulin and related proteins. Chemical and biological investigations. Presented at the annual meeting of the German Society for Internal Medicine, Wiesbaden April 1970

Dr. A. Teuscher

Med. Universitätsklinik

Inselspital Bern

CH-3010 Bern

Switzerland 